\title{
THE ROLE OF HIGHER EDUCATION INSTITUTIONS IN ENSURING INTEGRATED AND SUSTAINABLE REGIONAL DEVELOPMENT
}

\author{
Inga Jekabsone ${ }^{1}$, Dr.sc.admin. \\ ${ }^{1}$ RISEBA University College of Applied Sciences in Business, Arts and Technology
}

\begin{abstract}
Higher Education Institutions (HEIs) impact the development of their host regions. Systematic empirical research into the effects of HEIs on their host regions likewise has a long tradition. Even more, countless studies demonstrate the positive impact of HEIs on their regional environment. Various politicians, administrators and researchers have emphasised the role of HEIs in developing of territory there HEIs are operating. In addition, the focus of practitioners and academics has been on role of HEIs in ensuring integrated and sustainable development of their administrative territory.

Taking into account before mentioned, the aim of the paper is to analyse the role HEIs in ensuring integrated and sustainable regional development of the territory there HEIs are operating, especially in case of Latvia.

The tasks are formulated as follows:

1) to review the theoretical background on the role of HEIs in ensuring integrated and sustainable regional development;

2) to analyse empirical research on importance of HEIs in ensuring integrated and sustainable regional development;

3) to analyse case of Latvia, namely how HEIs in regions ensure integrated and sustainable regional development. In order to achieve the aim, following research methods have been used: scientific literature studies, statistical data analysis and case study method.

Main results and conclusions of the paper: the analysis of the scientific literature and empirical studies shows that HEIs matter the development of the host region and affect the integrated and sustainable regional development via channels of teaching, research and outreach activities. In case of Latvia, regional HEIs have dissimilar impact on integrated and sustainable development of the region through different teaching, research and outreach activities.
\end{abstract}

Key words: higher education institutions, regional development, sustainability.

JEL code: R11, I23, I25.

\section{Introduction}

HEIs matter to the development of their host regions. Even more, HEIs have the potential to spur a regional transition towards sustainability via the channels of teaching, research and outreach. Countless studies demonstrate the positive impact of HEIs on their regional environment.

The changing political and scientific discourse has influenced the engagement of HEIs in regional development in general, and sustainable development in particular. HEIs have developed and continue to develop from their "traditional" role as mere educational infrastructure and research institutions, to "new” roles as drivers for innovation and as stakeholders in public and private partnerships, as well as in planning processes (Chatterton and Goddard, 2000). This "3rd mission” depicts a broader and more adaptive role for HEIs, and their contribution to social, cultural and environmental development based on regional needs (Chatterton and Goddard, 2000; Gunasekara, 2006).

LozaNo et al. (2015) outline seven spheres where HEIs may engage in implementing sustainability:

1) institutional framework,

15. campus operations,

16. education,

1 jekabsone_inga@inbox.Iv; +371 27116147 
17. research,

18. outreach and collaboration,

19. on-campus experience,

20. assessment and reporting.

Stephens et al. (2008) deepen the definition of sustainable development by not only focusing on the activities of HEIs, but also by taking the content of teaching and research activities into account. They apply the term "change agent" to describe four paths of university action supporting sustainable transitions:

1) providing a model of sustainable practices for society;

21. teaching students how to deal with complex problems and exercise system-thinking;

22. performing practice based research-activities; and

23. promoting and enhancing engagement between individuals and universities situated as transdisciplinary agents.

Taking into account before mentioned, as well as recent public discussion on role of HEIs on development of Latvia and importance of regional HEIs in context of regional development, the analysis on importance of Latvian regional HEIs on integrated and sustainable development is needed.

The hypothesis of the research: regional HEIs of Latvia have limited impact on integrated and sustainable regional development of the region.

The aim of the paper is to analyse the role HEIs in ensuring integrated and sustainable regional development of the territory there HEIs are operating, especially in case of Latvia.

The tasks are formulated as follows:

1) To review the theoretical background on the role of HEIs in ensuring integrated and sustainable regional development;

2) To analyse empirical research on importance of HEIs in ensuring integrated and sustainable regional development;

3) To analyse case of Latvia, namely how HEI in regions ensure integrated and sustainable regional development.

In order to achieve the aim, following research methods have been used: scientific literature studies, statistical data analysis, case study method.

Novelty and topicality of the research: in case of Latvia, there had been conducted studies on impact of HEIs on economy of Latvia. The aspect of impact of regional HEIs on integrated and sustainable development of region has not been analysed yet.

\section{Problematic questions of the conducted research:}

1) How to formulate integrated and sustainable regional development for further research on regional HEIs impact on it?

2) What indicators could be used to analyse the impact on integrated and sustainable regional development?

During the research, following information sources were used: scientific literature, published empirical studies, statistical data, official websites of regional HEIs, and published interviews with experts.

Delimitations of research subjects: in case of Latvia, attention would be focused on regional HEIs (not on branches of HEIs located in Riga). 


\section{Theoretical discussion}

Systematic empirical research into the effects of HEIs on their host regions likewise has a long tradition. Initially, much of this research focused on how the expenditures of HEI, faculty, staff and students affect their host regions through direct and indirect "demand-side" effects of consumption and investment (Blume et al., 2017). Time and again, researchers estimated these effects to be substantial (Drucker and Goldstein, 2007). It is similarly well-established that HEIs exert "supplyside" effects through the production of graduates (Stephan, 2012).

Case study evidence supporting the notion of HEIs as important players in regional innovation systems abounds. Many observers have noted the role that Stanford University, and also UC Berkeley, played in Silicon Valley's ascent to become the global centre of the computer industry and related high-tech activities (Kenney and Mowery, 2014; Klepper, 2016).

Moving from individual cases to a more aggregate econometric approach, the impact of HEI research on regional innovation was shown in numerous empirical contexts including, e. g., Germany (Fritsch and Slavtchev, 2007; Schubert and Kroll, 2014), or Italy (Cowan and Zinovyeva, 2013).

In a broader definition of the "third mission", HEIs are also expected to engage in their region's social and societal deliberation and decision-making processes (Chatterton and Goddard, 2000; Breznitz and Feldman, 2012). In this context, sustainability has become an important issue. However, the definitions of what sustainability means are still diverse (Pike et al., 2007). Agreement exists on the belief that sustainability should encompass economic, but also social and environmental objectives (Brundtland, 1987).

Radinger-Peer and Pflitsch (2017) concentrate on another aspect of HEIs' third mission and study the contribution of HEIs to the regional transition towards sustainability. Brenner and Pflitsch (2017) look at the opposite causal direction and examine whether research at HEIs - in this case research on sustainability - is influenced by local circumstances. While sustainability was originally a rather politically developed and propagated concept, it has become a central issue in many disciplines in the meantime. The political focus on this topic - expressed for example in the Global Sustainable Development Goals - has provided new impetus and new resources to this field (Blume et al., 2017).

In this context, sustainable regional development has become an important issue. The literature on regional sustainability transitions takes a specific perspective. In line with the concept of sustainability transitions (Geels, 2011), it is argued that a systemic transition affecting various sociotechnical regimes is necessary within the region (McCormick et al., 2013). Leadership plays a crucial role in such a transition (Horlings and Padt, 2013).

Empirical studies show that at the regional level actors initiate more general institutional and organisational changes that lay the foundation for changes in multiple socio-technical regimes and thematic areas. Over time, incremental changes can this way lead to a more fundamental change in direction of a regional path towards sustainability (Rohracher and Spath, 2014; Strambach and Pflitsch, 2017).

In a more general understanding, the model of the "engaged HEI" attempts to conceptualize the comprehensive role HEIs may play for their location region, thus going beyond mere recognition of economic impacts - as argued by the Regional Innovation System Model as well as the "entrepreneurial model" - of HEIs activities (Radinger-Peer and Pflitsch, 2017). The "engaged HEI" characterizes HEIs as active "animateurs" (Shiri et al., 2012), which are capable of providing tailormade solutions to region-specific challenges and problems (e.g. urban development, transport, health, sustainable development). Also the term "change agent" (Stephens et al., 2008) raises the 
expectation that HEIs have the potential to take agency and thus trigger institutional and organisational changes in the regional path.

Recent research (Radinger-Peer and Pflitsch, 2017) revealed that HEIs have the potential to enact institutional and organisational change and thus spur a regional transition towards sustainability via the channels of teaching, research and outreach. Activities to incorporate sustainability into teaching are highly dependent on the bottom-up motivation of single faculty members and the top-down consolidation of the university management. Research activities in contrast are shaped by field-level drivers such as national and international funding programmes as well as regional allocation of contract research. Especially outreach activities have proven to have also a strategic dimension of ensuring future funding or taking agency to trigger structural change.

Researchers generalized that there is No role played by HEIs as a whole in sustainable regional development, but as a multi-level organisation, different spheres within the HEI ranging from HEI management to individual researchers have become active. In addition, researchers deduced that the role of HEIs in sustainable regional development has to be regarded as the result of the dynamic interplay of HEIs, regional and state level actors (Radinger-Peer and Pflitsch, 2017).

\section{Research results and discussion}

In this section case study of regional HEIs of Latvia will be analysed in context of integrated and sustainable regional development.

According to current situation, there are six state-funded regional HEIs (Fig. 1):

- Daugavpils University (DU);

- Latvia University of Life Sciences and Technologies (LLU);

- Liepaja University (LiepU);

- Rezekne Academy of Technologies (RTA);

- Ventspils University College (VeA);

- Vidzeme University of Applied Science (ViA).

Source: author's illustration

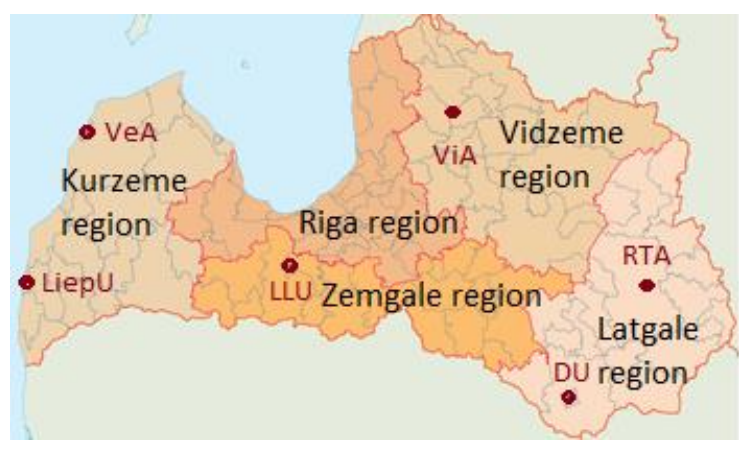

Fig. 1. HEIs in the regions of Latvia

In order to comprehensively characterise regional HEIs, the analysis of main indicators is provided in Table 1. 
Main indicators of regional HEIs in Latvia

\begin{tabular}{|c|c|c|c|c|c|}
\hline HEI & $\begin{array}{c}\text { Year of } \\
\text { foundation }\end{array}$ & Faculties & $\begin{array}{l}\text { Number of } \\
\text { students } \\
2017 / 18\end{array}$ & $\begin{array}{l}\text { Number of } \\
\text { academic } \\
\text { personnel } \\
2017 / 18\end{array}$ & $\begin{array}{l}\text { Number of } \\
\text { publications } \\
\text { per } 1 \text { acad. } \\
\text { personnel* }\end{array}$ \\
\hline DU & 1921 & $\begin{array}{l}\text { Faculty of Natural Sciences and } \\
\text { Mathematics, Faculty of Education and } \\
\text { Management, Faculty of Music and } \\
\text { Arts, Faculty of Social Sciences, } \\
\text { Faculty of Humanities }\end{array}$ & 2379 & 110 & 68 \\
\hline LLU & 1938 & $\begin{array}{l}\text { Faculty of Agriculture, Forest Faculty, } \\
\text { Faculty of Veterinary Medicine, Faculty } \\
\text { of Engineering, Faculty of Environment } \\
\text { and Civil Engineering, Faculty of Food } \\
\text { Technology, Faculty of Economics and } \\
\text { Social Development, Faculty of } \\
\text { Information Technologies }\end{array}$ & 4176 & 279 & 20 \\
\hline LieU & 1954 & $\begin{array}{l}\text { Faculty of Science and Engineering, } \\
\text { Faculty of Humanitarian Sciences and } \\
\text { Arts, Faculty of Pedagogy and Social } \\
\text { Work, Faculty of Management and } \\
\text { Social Sciences }\end{array}$ & 1356 & 75 & 8 \\
\hline RTA & 1993 & $\begin{array}{l}\text { Faculty of Education, Languages and } \\
\text { Design, Faculty of Engineering, Faculty } \\
\text { of Economics and Management }\end{array}$ & 1881 & 84 & 12 \\
\hline VeA & 1997 & $\begin{array}{l}\text { Faculty of Information Technologies, } \\
\text { Faculty of Economics and } \\
\text { Management, Faculty of Translation } \\
\text { Studies }\end{array}$ & 817 & 37 & 20 \\
\hline ViA & 1996 & $\begin{array}{l}\text { Faculty of Society and Science, Faculty } \\
\text { of Engineering }\end{array}$ & 768 & 58 & 0 \\
\hline
\end{tabular}

*full time equivalent, 2015

Source: author's calculations based on Ministry of Education and Science, 2018

LLU stands out with highest number of students and academic personnel and wider range of faculties and study programmes. DU - university with long history - is distinguished not only with relatively high number of students and academic personnel but with outstanding research results in comparison with other regional HEIs. LiepU and RTA show average results in teaching and research. VeA as most recently established HEI shows good results in research, while ViA focuses more in teaching.

In order to analyse the impact of regional HEIs on region, the share of students matriculated in full-time studies in regional HEIs depending on place of residence is provided (Table 2).

Share of students matriculated in full-time studies in regional HEIs depending on place of residence

\begin{tabular}{|l|c|c|c|c|c|}
\hline HEI & Riga region & Vidzeme region & Kurzeme region & Zemgale region & Latgale region \\
\hline DU & 0.04 & 0.04 & 0.02 & 0.07 & 0.83 \\
\hline LLU & 0.32 & 0.10 & 0.12 & 0.40 & 0.06 \\
\hline LieU & 0.17 & 0.04 & 0.75 & 0.04 & 0 \\
\hline RTA & 0.07 & 0.07 & 0 & 0.03 & 0.83 \\
\hline VeA & 0.15 & 0.03 & 0.74 & 0.07 & 0.01 \\
\hline ViA & 0.25 & 0.62 & 0.02 & 0.06 & 0.05 \\
\hline
\end{tabular}

Source: author's calculations based on Ministry of Education and Science, 2018

It can be concluded that in case of DU, LiepU and RTA mayor share of matriculated students resides in relevant region. In case of LLU and ViA - significant share of matriculated students resides in relevant region, however because of geographical location of LLU and ViA students from other 
regions choose these HEIs for studies. Taking into account the data about residence of matriculated students, it can be concluded that regional HEIs play significant role in providing the education for regional future labour.

In order to investigate the role of regional HEIs in ensuring sustainable and integrated regional development in Latvia, activities of these HEIs were analysed in terms of teaching, research and outreach that corresponds to integrated and sustainable development of the region (Table 3).

Table 3

\section{Activities of regional HEIs in teaching, research and outreach towards integrated and sustainable regional development}

\begin{tabular}{|c|c|c|c|}
\hline HEI & $\begin{array}{l}\text { Teaching } \\
\end{array}$ & Research & Outreach \\
\hline DU & $\begin{array}{l}\text { Study programmes „Environmental } \\
\text { Science”, "Environmental Planning" } \\
\text { Concept of sustainable and } \\
\text { integrated regional development is } \\
\text { included in various study } \\
\text { programmes (e.g. study } \\
\text { programme "Biology", "Civil } \\
\text { Security and Protection", "Natural } \\
\text { Recreation") and study courses }\end{array}$ & $\begin{array}{l}\text { Research projects on regional development } \\
\text { and sustainability (e.g. EEA/Norway grants } \\
\text { projects "Promoting the Research Potential of } \\
\text { Higher Education Institutions for Regional } \\
\text { Development", "Role of social and economic } \\
\text { networks in territorial development") } \\
\text { Master and PhD thesis }\end{array}$ & $\begin{array}{l}\text { Annual international and local } \\
\text { scientific conferences (reports and } \\
\text { section related to regional } \\
\text { development and environmental } \\
\text { science) } \\
\text { Scientific-practical conference } \\
\text { "Happy Children in a Safe } \\
\text { Environment" } \\
\text { "Green Biology School" for pupils }\end{array}$ \\
\hline LLU & $\begin{array}{l}\text { Faculty of Environment and Civil } \\
\text { Engineering } \\
\text { Study programmes „Forest Ecology } \\
\text { and Forestry", "Environmental, } \\
\text { Water and Land Engineering", } \\
\text { "Environment and water } \\
\text { management" } \\
\text { Concept of sustainable and } \\
\text { integrated regional development is } \\
\text { included in various study } \\
\text { programmes (e.g. study } \\
\text { programme "Landscape } \\
\text { Architecture and Planning", } \\
\text { "Economics", "Land use and land } \\
\text { surveying") } \\
\text { Wide range of lifelong learning } \\
\text { study courses that cover regional } \\
\text { development topics }\end{array}$ & $\begin{array}{l}\text { Doctoral study programme „Environmental } \\
\text { Engineering", "Agrarian and regional } \\
\text { economy" } \\
\text { Priority research directions „Research on } \\
\text { climate change and environmental } \\
\text { technologies, hydrology and agriculture”, } \\
\text { "Exploring the potential for sustainable } \\
\text { development of territories", "Economics of } \\
\text { sustainable development of bio-resource } \\
\text { industries" } \\
\text { Co-usage of research infrastructure that } \\
\text { promotes sustainable regional development }\end{array}$ & $\begin{array}{l}\text { Participation in development of } \\
\text { pupils research work, including } \\
\text { environmental topics } \\
\text { Scientific conferences like } \\
\text { "Bioeconomy and Rural } \\
\text { development", "Engineering for } \\
\text { Rural Development", "Rural } \\
\text { Environment. Education. } \\
\text { Personality" } \\
\text { LLU Bioeconomy and Sustainable } \\
\text { Resource Management Center } \\
\text { activities: seminars, forums, } \\
\text { participation in working groups } \\
\text { with policy planners } \\
\text { Consultations with industry on } \\
\text { different topics related to } \\
\text { sustainable regional development } \\
\text { Participation in different networks } \\
\text { that promote sustainable and } \\
\text { integrated regional development } \\
\text { (The Baltic University Programme, } \\
\text { Baltic Sea Region University } \\
\text { Network etc.) }\end{array}$ \\
\hline LieU & $\begin{array}{l}\text { Study programme „Environment } \\
\text { and Renewable Energy } \\
\text { Management and Engineering" } \\
\text { Concept of sustainable and } \\
\text { integrated regional development is } \\
\text { included in some study courses }\end{array}$ & $\begin{array}{l}\text { NordPlus project "Practical Approach for } \\
\text { teaching Circular Economy", INTERREG } \\
\text { project "Improving smart specialisation } \\
\text { implementation of the Baltic Sea Region } \\
\text { through orchestrating innovation hubs" } \\
\text { (SMART-UP), EEA/Norway project } \\
\text { "Development of Educational module "Climate } \\
\text { change" at LiepU", }\end{array}$ & $\begin{array}{l}\text { Participation in development of } \\
\text { pupils' research work, that may } \\
\text { cover regional development issues }\end{array}$ \\
\hline RTA & $\begin{array}{l}\text { Study programme „Environmental } \\
\text { engineer" } \\
\text { Concept of sustainable and } \\
\text { integrated regional development is } \\
\text { included in some study courses }\end{array}$ & $\begin{array}{l}\text { Regional Institute of Regional Studies } \\
\text { Master and PhD thesis on topics that include } \\
\text { regional development issues } \\
\text { Project "Effects of Structural and Social } \\
\text { Change on Municipalities in Germany and the } \\
\text { Baltic States" (CliMBinG) } \\
\end{array}$ & $\begin{array}{l}\text { International Student Scientific- } \\
\text { Practical Conference "Man. } \\
\text { Environment. Technology" } \\
\text { International Scientific-Practical } \\
\text { Conference "Environment. } \\
\text { Technology. Resources" } \\
\end{array}$ \\
\hline VeA & $\begin{array}{l}\text { Concept of sustainable and } \\
\text { integrated regional development is } \\
\text { included in some study courses }\end{array}$ & $\begin{array}{l}\text { Center for Entrepreneurship, Innovation and } \\
\text { Regional Development (supported by } \\
\text { Ventspils Municipality) - elaborates research } \\
\text { according to the needs of the Municipality }\end{array}$ & $\begin{array}{l}\text { Integrated and comprehensive } \\
\text { cooperation with municipality } \\
\text { International scientific conference } \\
\text { "Entrepreneurship, Innovation and } \\
\text { Regional Development - EIRD } \\
2017 \text { Smart Growth of the Local } \\
\text { Community in the Global World" } \\
\text { Forum "Challenges in Kurzeme on } \\
\text { the Way to Smart Economy" } \\
\end{array}$ \\
\hline ViA & $\begin{array}{l}\text { Concept of sustainable and } \\
\text { integrated regional development is } \\
\text { included in some study courses }\end{array}$ & $\begin{array}{l}\text { Medium-term objective of research is to } \\
\text { promote the development of national and } \\
\text { Vidzeme region smart specialization sectors } \\
\text { and increase productivity by carrying out } \\
\text { research in the direction of topical public and } \\
\text { technological challenges }\end{array}$ & $\begin{array}{l}\text { Smart Lunch with Maris Olte } \\
\text { (famous spokesman of } \\
\text { environmental issues) } \\
\text { International Scientific-Practical } \\
\text { Conference "SOCIETY. } \\
\text { TECHNOLOGIES. SOLUTIONS." } \\
\text { Student research conference } \\
\text { "SOCIETY. TECHNOLOGIES. } \\
\text { SOLUTIONS. " }\end{array}$ \\
\hline
\end{tabular}


It can be concluded that all regional HEIs include concept of sustainable and integrated regional development in some study courses; some of them implement study programmes that are especially devoted to sustainable regional development (DU, LLU, LiepU and RTA). Good practice on promotion integrated and sustainable regional development includes establishment of close cooperation with local and regional authorities by elaboration of research on topics that are topical for local and regional development, organization of comprehensive outreach events including different stakeholders, participation in policy planning, providing consultations and services for local entrepreneurs, and ensuring life-long study courses for local society. Especially, cases of LLU and VeA outstand with different activities that promotes integrated and sustainable development, focusing on dealing with regional challenges and active participation in decision-making processes with local, regional and even national authorities. Other HEIs have rather limited impact on integrated and sustainable development of the region.

\section{Conclusions, proposals, recommendations}

1) HEIs impact the development of their host regions. Systematic empirical research into the effects of HEIs on their host regions likewise has a long tradition. Empirical research had demonstrated that HEIs have the potential to spur a regional transition towards sustainability via the channels of teaching, research and outreach.

2) The hypothesis of the research - regional HEIs of Latvia have limited impact on integrated and sustainable regional development of the region - has approved partly. HEIs like LLU and VeA showed systemic approach on participation in integrated and sustainable regional development of the region by comprehensive teaching, research and outreach activities. Other HEIs perform different activities that corresponds to integrated and sustainable regional development, however these activities are rather fragmented and more relate to common mission of HEI.

3) Latvian regional HEIs should put as a priority establishing productive relationships with local and regional authorities (on issues of regional development - with national authorities) in order to serve the needs of the region. Good practice includes developing research directions according to the needs of the region, organizing and participating in different outreach activities aimed at integrated and sustainable regional development as well as involving the concept of integrated and sustainable regional development in teaching.

\section{Bibliography}

1. Blume, L., Brenner, T., Buenstorf, G. (2017). Universities and Sustainable Regional Development: Introduction to the Special Issue. Review of Regional Research, Volume 37, Issue 2, pp. 103-109.

2. Brenner, T., Pflitsch, G. (2017). The Raise of Publications on Sustainability - a Case Study in Germany. Review of Regional Studies, Volume 37, pp. 189-225.

3. Breznitz, S.M., Feldman, M.P. (2012). The Engaged University. The Journal of Technology Transfer, Volume 37, pp. 139-157.

4. Brundtland, G.H. (1987). Report of the World Commission on Environment and Development: "Our Common Future". United Nations, Oslo.

5. Chatterton, P., Goddard, J. (2000). The Response of Higher Education Institutions to Regional Needs. European Journal of Education, Volume 35, pp. 475-496.

6. Cowan, R., Zinovyeva, N. (2013). University Effects on Regional Innovation. Research Policy, Volume 42, Issue 3, pp. 788-800.

7. Drucker, J., Goldstein, H. (2007). Assessing the Regional Economic Development Impacts of Universities: a Review of Current Approaches". International Regional Science Review, Volume 30, pp. 20-46.

8. Fritsch, M., Slavtchev, V. (2007). Universities and Innovation Space. Industry and Innovation, Volume 14, Issue 2, pp. 201-218.

9. Gunasekara, C. (2006). Academia and Industry. The Generative and Development Roles of Universities in Regional Innovation Systems. Science and Public Policy, Volume 33, Issue 2, pp. 137-150. 
10. Kenney, M., Mowery, D.C. (eds) (2014). Public Universities and Regional Growth: Insights from the University of California. Stanford University Press, Palo Alto.

11. Klepper, S. (2016). Experimental Capitalism: the Nanoeconomics of American high-tech industries. Princeton University Press, Princeton.

12. Lozano, R. et al. (2015). A Review of Commitment and Implementation of Sustainable Development in Higher Education: Results form a Worldwide Survey. Journal of Clean Production, Volume 108, pp. 1-18.

13. Parskats par Latvijas augstako izglitibu 2017.gada galvenie statistikas dati (Latvia's Higher Education Report 2017, Main Statistical Data) (2018) Ministry of Education and Science of Latvia, 98 p. Retrieved: http://www.izm.gov.Iv/images/zinatne/Prskats-par-Latvijas-augstko-izgltbu-2017.gad_2.pdf Access: 16.02.2019.

14.Pike, A., Rodriguez-Pose, A., Tomaney, J. (2007). What Kind of Local and Regional Development and for Whom? Regional Studies, Volume 41, Issue 9, pp. 1253-1269.

15. Radinger-Peer, V., Pflitsch, G. (2017). The Role of Higher Education Institutions in Regional Transition Paths towards Sustainability. The Case of Linz (Austria). Review of Regional Research, Volume 37, Issue 2, pp 161-187.

16. Rohracher, H., Spath, p. (2014). The Interplay of Urban Energy Policy and Socio-technical Transitions: The Eco-cities of Graz and Freiburg in Retrospect. Urban Studies, Volume 51, Issue 7, pp. 1415-1431.

17. Schubert, T., Kroll, H. (2014). Universities' Effects on Regional GDP and Unemployment: the Case of German. Papers in Regional Science, Volume 1, pp. 1-24.

18. Shiri, M., Breznitz, M., Feldman, p. (2012). The Engaged University. Journal of Technology Transfer, Volume 35, pp. 139-157.

19.Stephan, P.E. (2012). How Economics Shapes Science. Harvard University Press, Cambridge.

20.Stephens, J.C. et al. (2008). Higher Education as a Change Agent for Sustainability in Different Cultures and Contexts. International Journal of Sustainable Higher Education, Volume, 9, Issue 3, pp. 317-338.

21. Strambach, S. (2010). Path Dependence and Path Plasticity: The Co-evolution of Institutions and Innovation in the German Customized Business Software Industry. In: Boschma, R., Martin, R. (eds) The Handbook of Evolutionary Economic Geography. Edward Elgar Publishing Limited, Cheltenham, pp. 406-431. 